\title{
Fundamentals of Scientific Literacy: A Proposal for Science Teacher Education Program
}

\author{
Susan Bruna Carneiro Aragão, Maria Eunice Ribeiro Marcondes \\ Programa de Pós-graduação Interunidades - University of São Paulo - Brazil
}

\begin{abstract}
Scientific Literacy (SL) is a term used in many countries to define the purpose of science education. Although there is no consensus in defining it, many authors argue that SL is the main goal for science education. Based on author's previous research that established three fundamentals of $S L$ that can develop students' scientific literacy, the approaches: Inquiry-based Teaching (IBT), Science-TechnologySociety (STS), and History and Philosophy of Science (HPS), an academic discipline in a teacher education program was investigated in order to analyze pre-service teachers' conceptions about SL and its fundamentals. The research objective was investigated how pre-service teachers understand and reflect on the SL concept and its fundamentals. This proposal was applied in a Brazilian Federal University located in the metropolitan area of São Paulo-Brazil. Twelve pre-service teachers attended the seventeen classes. They studied three different approaches: STS, HPS, and IBT. Some aspects of Nature of Science were also considered. Researchers authors elaborated levels of comprehension for each approach in order to analyze pre-service teachers' conceptions. The primary results so far indicated that some students were able to establish relationships among these approaches and their comprehension of each approach was dependent on the emphasis of the teacher educator.
\end{abstract}

\section{Introduction}

Scientific literacy (SL) is a concept considered by many countries since the second half of the $20^{\text {th }}$ century. From that time, researches discussed what the purpose of teaching science is and what students should learn to become scientifically literate.

Even though there is no consensus in defining it, many authors argue that scientific literacy is the main goal of science education [1] [2] [3] [4] [5].

In countries with languages originating in Latin, there is a difficulty in translating the term "Scientific Literacy". In the French publications, we find at least two expressions: "Alphabétisation Scientifique" and "Culture Scientifique". For the Belgian researcher Gerard Fourez prefers the term "Alphabétisation Scientifique et Technique", even though in UNESCO documents, the English term literacy was translated by the word "culture" and not "literacy". Spanish- language authors, for example, often use the term "Alfabetización Científica" [3].

In Brazil, there is also a great debate because of the translation of the term "scientific literacy" from the English language into the Portuguese language. There are at least three translations:

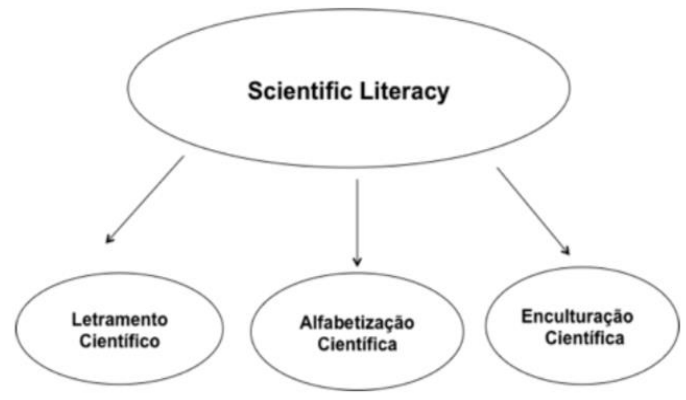

Figure 1. The three different translations of the term "Scientific Literacy" from the English language to the Portuguese language [1]

In the Brazilian context, Santos and Mortimer [6] prefer to use the term "Letramento Científico". They justify the use of this term because "it is sought to emphasize the social function of science education in opposition to the restricted meaning of school literacy". He argues that the difficulty of finding a standard definition is due to the existence of different groups of social actors concerned with science education. Each of these groups of educators, economists, journalists, sociologists, among others, have different definitions for the concept of scientific literacy, different purposes for teaching science, and different strategies for measuring people's level of literacy in science. Thus, each group defines Scientific Literacy with a different focus and purpose. The author also states that the function and meaning of science education are transformed the social context in which we live. For example, in the 1950s, with the Cold War, the purpose of science education was to train scientists and technologists. So, science education was based on the scientific method. However, later, in the 1970s, the STS (Science-Technology-Society) approach emerged, which remains to this day. Besides, the author points out that currently there is the concern of teaching science to educate students who wish to participate in the selective processes for entry into higher education, so the format of teaching, in the vast 
majority, is the traditional, content-based only. On the other hand, there is also interest in forming critical and reflexive citizens, and with a contextualized teaching approach, with STS relations. It can be inferred that teaching is adjusting according to the changing social context in which we live [6].

For Sasseron and Carvalho [3] prefer the term "Alfabetização Científica" based on the idea of literacy conceived by Paulo Freire, "... literacy is more than the simple psychological and mechanical mastery of writing and reading techniques. It is the mastery of these techniques in conscious terms. (...) It implies a self-formation that may result in an interfering posture of man on his context "(p.111, 1980, our translation).

For Chassot, Carvalho, and Tinoco prefer the term "Enculturação Científica" [3]. For them, science is a cultural production, and it is a language to understand the natural world. In this way, science education is strongly linked to citizenship issues, since the domain of scientific and technological knowledge is essential for the development of the citizen on a daily basis. From this knowledge, the citizen can participate in debates, criticize and discuss on social, economic, environmental and political issues that involve science. Chassot states, "... teaching science is to make sure that our students transform, with the teaching that we do, into more critical men and women. We dream that with our education, students can become agents of transformation - for the better - of the world in which we live." [3].

Although scientific literacy in Brazil is a polysemous concept, its definition is gaining increasing proportions because it encompasses content, procedures and attitudes.

In the Brazilian and international scenario, Scientific Literacy has become the common goal of science education.

\section{Scientific literacy: different views, common goals}

In the 70's, when industrialized society was growing, Benjamin S. P. Shen [7] published an article presenting three forms of scientific literacy: practical, civic, and cultural. A practical scientific literate person possesses the scientific and technical know-how and can apply them in everyday life. For him, this type of scientific literacy is the most needed for developing countries. Shen stated, "there should be a concerted worldwide effort to advance practical science literacy." A civic scientific literate person is concerned to scientific-related public issues and can engage in debates, to take a decision and evaluate benefits and risks by scientific evidence. To accomplish a functional level of civic science literacy, Shen argued, "the public must be far more exposed to science" and "science-related public issues must be analyzed in plain language for the average citizen." By that time, the cultural-scientific literate people corresponded to a small part of the population, only intellectual community. To conclude, Shen stated the idea that the scientific, technical language can be "translated" to "the ordinary language of everyday discourse without intolerable loss of meaning." For him, at that time, there was a need to popularize science. For this, he argued, "Projects in science literacy must be closely coordinated with projects in alphabetic literacy reading and writing."

At the same time, Milton O. Pella [8] argued that scientists started to enter in public scientific issues discussion, such as environmental problems, food production, genetics. This challenge made scientists and people beginning realizing that experimental research results affect society. This perception was arousing young people's interest in science. Even though the interest in science was growing, for Pella all people cannot understand science at the same level. So, to define scientific literacy as a common goal for "general literacy", he established eight terms [8]:

1. Concepts: these make up the vocabulary of science and are recognized to be both empirical and theoretical and to exist at different levels of complexity, sophistication, and abstraction.

2. Empirical Laws: these are the consistencies noted in the natural world and are verbalized utilizing the concepts, combining terms, and conventions.

3. Theoretical Laws: these are postulated consistencies in the natural world.

4. Regulatory Principles: these are the rules that determine the methods employed in developing concepts and laws as well as the criteria for their acceptance.

5. Explanation: the subsuming of events under laws, either theoretical or empirical.

6. Prediction: using facts and laws for cast events.

7. Science-Society Interaction: the use of the products of science and the demands of society concerning new products and areas of study as well as the demands of science regarding support and opportunities to develop.

8. Humanistic Implications: the historical development of knowledge and how it is interrelated with the culture.

Pella stated, "a scientifically literate citizenry understands some of the knowledge library of science, knows some of the limitations and potentials of the contents of the library, knows how and when to apply the knowledge library, knows where the contents of the library come from, and knows some of the regulatory principles involved in knowledge production and use" [8]. However, he was aware that 
science education is not enough to develop scientific literate citizenship. For him, "scientific literacy cannot exist as a single entity." The function of science education is to teach science, social studies, is to show social implications, and humanities, humanistic implications. So to accomplish literacy in science, must also achieve literacy in social studies and humanities.

Despite Pella's warning about the need to integrate science education with other disciplines, science education became more isolated, and school disciplines were more fractionated because of scientific development.

By the end of $20^{\text {th }}$ century, Paul Hurd, in his article "Scientific Literacy: New Minds for a Changing World" [9], argued a need to change science education and science curricula. For him, science and society views of science were changing. He stated, "Education in the sciences takes on new dimensions with the changing image of science/technology, a rapidly changing culture, and a knowledge-intensive era".

In this context, Hurd defined scientific literacy as "cognitive capacities for utilizing science/technology information in human affairs and for social and economic progress." Students who possess a set of higher order thinking skills and cognitive strategies are scientifically literate. This set of skills considered by Hurd is:

- Distinguishes experts from the uninformed.

- Distinguishes theory from dogma, and data from myth and folklore. Recognizes that almost every fact of one's life has been influenced in one way or another by science/technology.

- Knows that science in social contexts often has dimensions in political, judicial, ethical, and sometimes moral interpretations.

- Senses the ways in which scientific research is done and how the findings are validated.

- Uses science knowledge where appropriate in making life and social decisions, forming judgments, resolving problems, and taking action.

- Distinguishes science from pseudo-science such as astrology, quackery, the occult, and superstition.

- Recognizes the cumulative nature of science as an "endless frontier."

- Recognizes scientific researchers as producers of knowledge and citizens as users of science knowledge.

- Recognizes gaps, risks, limits, and probabilities in making decisions involving a knowledge

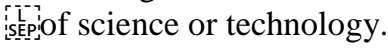

- Knows how to analyze and process information to generate knowledge that extends beyond ichepifacts.
- Recognizes that science concepts, laws, and theories are not rigid but essentially have an organic quality; they grow and develop; what is taught today may not have the same meaning tomorrow.

- Knows that science problems in personal and social contexts may have more than one "right" answer, especially problems that involve ethical, judicial, and political actions.

- Recognizes when a cause and effect relationship cannot be drawn.

- Understands the importance of research for its own sake as a product of a scientist's curiosity.

- Recognizes that our global economy is largely influenced by advancements in science and technology.

- Recognizes when cultural, ethical, and moral issues are involved in resolving science - social problems.

- Recognizes when one does not have enough data to make a rational decision or form a reliable judgment.

- Distinguishes evidence from propaganda, fact from fiction, sense from nonsense, and knowledge from opinion.

- Views science - social and personal - civic problems as requiring a synthesis of knowledge from different fields including natural and social sciences.

- Recognizes there is much not known in a science field and that the most significant discovery may be announced tomorrow.

- Recognizes that scientific literacy is a process of acquiring, analyzing, synthesizing, coding, evaluating, and utilizing achievements in science and technology in human and social contexts.

- Recognizes the symbiotic relationships between science and technology and between science, technology, and human affairs.

- Recognizes the everyday reality of ways in which science and technology serve human adaptive capacities, and enriches one's capital.

- Recognizes that science - social problems are generally resolved by collaborative rather than individual action.

- Recognizes that the immediate solution of a science - social problem may create a related problem later.

- Recognizes that short- and long-term solutions to a problem may not have the same answer.

\subsection{Scientific literacy and Curriculum reforms}

Shen's ideas about the three forms of scientific literacy [7], Pella's eight terms for defining "general literacy" [8], the set of skills considered by Hurd [9] 
and other ideas about scientific literacy, were considered in many curriculum reforms in the end of the $20^{\text {th }}$ century and begging of the $21^{\text {st }}$ century, with the aim to develop scientific literacy.

In 1998, Millar and Osborne from King's College University published the document "Beyond 2000: Science education for the future - The report of a seminar series funded by the Nuffield Foundation" [5]. The authors point out that for years, science education aimed to prepare students to be future scientists. However, in today's society, due to the increase of scientific questions, there is a demand for the expansion of knowledge and understanding of the population in general, so that it can accompany debates of scientific and technological nature. In this way, they define that the current purpose of science education is to prepare young people for a full and satisfying life, rich in information, in the world of the 21 st century. And they state that "The science curriculum from 5 to 16 should be seen primarily as a course to enhance general "scientific literacy'." (p. 13).

In 2001, the American Association for Advanced Science launched the "Project 2061: Science for All Americans" [4] pedagogical project to "help all Americans become literate in science, mathematics, and technology." This project established the benchmarks for Science Literacy, showing five recommendations to help educators rethink their curriculum.

1. Describes levels of understanding and ability that all students are expected to reach on the way to becoming science literate;

2. Concentrates on the common core of learning that contributes to the science literacy of all students while acknowledging that most students have interests and abilities that go beyond that common core, and some have learning difficulties that must be considered;

3. Avoids language used for its own sake, in part to reduce sheer burden, and in part to prevent vocabulary from being mistaken for understanding;

4. Is informed by research on how students learn, particularly as it relates to the selection and grade placement of benchmarks; and

5. Encourages educators to recognize the interconnectedness of knowledge and to build these important connections into their curriculum units and materials.

In 2016, the Australian Curriculum, Assessment and Reporting Authority published the Australian Curriculum [10] establishing the expectations for what all young Australians should be taught, with the focus on literacy to develop "the ability to use scientific knowledge, understanding and skills to identify issues, acquire new knowledge, explain scientific phenomena, solve problems and draw conclusions based on evidence, recognize that science can help us to make responsible decisions and shape our interpretations of information."

In 2017, the Brazilian Ministry of Education published the document "Base Nacional Comum Curricular (BNCC)" [11] which presents the content and skills for Pre-primary, primary, and lower secondary levels of education.

Table 1. Correspondence between ISCED 97 and Brazilian educational levels

\begin{tabular}{|c|l|}
\hline ISCED 97 levels & $\begin{array}{l}\text { Brazilian educational } \\
\text { levels }\end{array}$ \\
\hline $\begin{array}{l}\text { ISCED 0 (Pre-primary } \\
\text { level of education) }\end{array}$ & $\begin{array}{l}\text { Creche and Pré-escola } \\
\text { Kindergarten (from 3 years } \\
\text { old) }\end{array}$ \\
\hline $\begin{array}{l}\text { ISCED 1 (Primary } \\
\text { level of education) }\end{array}$ & $\begin{array}{l}\text { Ensino fundamental (1 }{ }^{\text {o }} \text { ao } \\
5^{\circ} \text { ano) ou equivalente } \\
\text { Fundamental Education (1 } \\
\text { to } 5^{\text {th }} \text { year or equivalent) }\end{array}$ \\
\hline $\begin{array}{l}\text { ISCED 2 (Lower } \\
\text { secondary level of } \\
\text { education) }\end{array}$ & $\begin{array}{l}\text { Ensino fundamental }\left(6^{\text {o }} \text { a }\right. \\
9^{\circ} \text { ano) ou equivalente) } \\
\text { Fundamental Education (6 } \\
\text { to } 9^{\text {th }} \text { year or equivalent) }\end{array}$ \\
\hline $\begin{array}{l}\text { ISCED } 3 \text { (Upper } \\
\text { secondary level of } \\
\text { education) }\end{array}$ & $\begin{array}{l}\text { Ensino médio (1 }{ }^{\text {a }} \text { a } 3^{\text {a }} \\
\text { séries) } \\
\text { High School }\end{array}$ \\
\hline
\end{tabular}

In the field of Science, BNCC determinations for science education are to promote the development of scientific literacy. It defines SL as "the ability to understand and interpret the world (natural, social, and technological), but also to transform it based on the theoretical and procedural contributions of the sciences" [11].

As we can see, all documents established scientific literacy as a goal for science education.

According to Shamos, in his book "The Myth of Scientific Literacy" [12], he argues that the massive reform movement in science education to improve scientific literacy is flawed because the reforms focus on curriculum design. However, for Shamos, government leaders in education, researchers, and curriculum designers do not take into account the question: "Why should we teach science?". Since this is a philosophical question, it does not seem to be considered at the core of the discussions about science education.

So, what we can see instead of it, in Brazil, at the beginning of the $21^{\text {st }}$ century, the research in science education turned to teacher education and science education approaches.

\subsubsection{Inquiry-based learning (IBL) approach} Several authors recommend Inquiry-based teaching as a highly valued approach in science education [1] [3]. In many curricula, there is also an orientation for science teachers to work with these activities. In the Brazilian National Curricular Parameters and the 
new document "Base Nacional Comum Curricular" there is also this recommendation [11].

This approach is widely recommended because it has the potential to promote understanding of phenomena in light of science and the development of other competencies [13]. It is an approach that encompasses many facets of reality that provide students with observations, problem identification.

Bybee [14] presents the following essential characteristics for inquiry-based teaching in the science classroom:

- apprentices engaged in a scientifically oriented question;

- apprentices who prioritize the evidence to answer the proposed question;

- apprentices who use the evidence to develop explanations;

- learning connected to explanations to scientific knowledge;

- learners communicate and justify the explanation.

He also argues that his proposal is focused on the cognitive activities of apprentices, clearly oriented to science and whose goal is to develop scientific education. Thus, the apprentice relates the explanation to scientific knowledge, elaborates justifications and communicates them.

\subsubsection{Science-Technology-Society (STS) approach}

Science education focused on scientific literacy pursuit the learning of scientific concepts and also goes beyond this dimension, intends to form the students integrally, seeking other areas of knowledge such as technology, society, the environment and the formation of citizenship [1] [3] [6] [14]. Therefore, teaching with an STS approach is in line with scientific literacy [1] [6].

According to Aikenhead [15], which critique the traditional science instruction, argues the relevance of context play a fundamental role in science education

So, the STS (Science-Technology-Society) approach, knowledge ceases to be the guiding center of teaching, and the student starts to play a central role in the construction of scientific concepts, allowing them to relate science with technology and society. Graphically, Aikenhead illustrated this idea as in Figure 2.

According to Aikenhead's STS model [15], science education must start with social issues problems related to science and technology. The understanding of the scientific concepts can be applied again in situations of social context, as illustrated in Figure 3.

In order to carry out a science education with STS approach it is necessary to promote discussions among teachers in both initial and continuing education, in order to problematize and systematize theoretical knowledge about contextualized teaching [1].

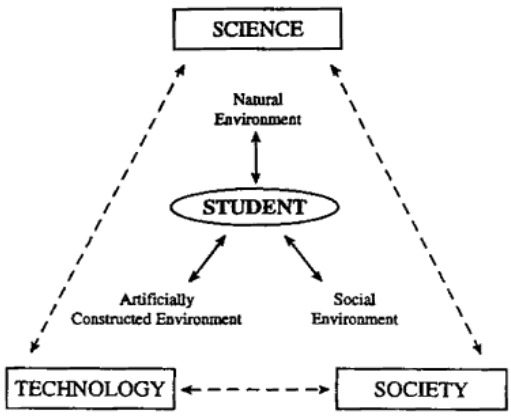

Figure 2. The essence of STS education [15]

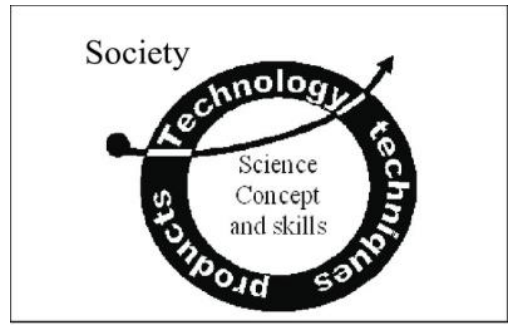

Figure 3. A sequence for STS Science Teaching [15]

Acevedo, Vázquez e Manassero [16] argue that the STS approach has been underestimated in science education and that teachers have not taken into account the fact that it can provide a better understanding of the nature of science. According to these authors, this is probably due to the low incidence of the STS approach in classroom practice.They also affirm that the STS approach, over the years, incorporated some aspects of the Nature of Science (NoS), mainly for those that deal with the internal and external sociology of science.

The STS approach, therefore, is important for science education, not only because it can provide the relationships between Science-TechnologySociety, but also for the understanding the nature of science [1].

2.1.3. History and Philosophy of Science (HPS) approach Many science education researchers [1] [17] [18] defend the use of the approach of History and Philosophy of Science (HPS) in science education.

According to Allchin [2], "the HPS approach to scientific education evokes a vast network that extends from the breadth of science studies to functional scientific literacy in socio-scientific issues."

Many curricula also consider it important to develop students' view of the Nature of Science (NoS). The HPS approach is quite effective in 
working with this aspects, which is an integral component of scientific literacy [2] [4] [5] [11] [17] [18].

Some researchers are concerned with developing science teachers' views on (NoS), because teachers' conceptions will directly influence their classroom practices [17].

However, in general, aspects of the NoS are not addressed in teacher education, and these, when in the classroom, face obstacles to teaching science with an approach that values HPS. According to the literature review by Niaz [17], many teachers have an inadequate understanding of the nature of science. Hence, the author recommends that caution is needed when dealing with aspects of NoS and the HPS approach, because of their complexity, and suggests that science teachers in basic education do not have an adequate understanding of $\mathrm{NoS}$, since practically it does not is treated in the science teacher education courses and, when they are in the classroom, they face several obstacles.

\section{Fundamentals of Scientific Literacy}

For this work, we considered a scientifically literate person is able to [1]:

- Know how to use scientific language: reading, writing, and systematize the scientific acknowledgement.

- Understand main concepts, principles and scientific theories.

- Know how to apply scientific acknowledgement in historical, social and environmental contexts.

- Understand science nature: standards, research, scientific method and nature of science.

- Understand how science and technology work together.

- Understand the impact of science and technology in society.

Although this is the aim for science education, in Brazil the reality is kind different. The results of PISA 2015 [19], the average score of young Brazilian students in the science assessment was 401 points, a substantially lower value than the average of OECD member countries' students (493 points).

We also have some problems related to teacher education. In Brazil, to become a science teacher, the undergraduate student must attend a specific course, consisted of a solid base on content (choosing one area: Chemistry, Physics or Biology) and complementation with pedagogical disciplines. This type of teacher education program can lead to fragmentation of specific science contents and pedagogical practice. So, when these teachers face with the great challenge of teaching this discipline, which has a tradition of being difficult because of the high degree of abstraction, they often make use of more traditional teaching approaches.

Many authors point to the need to integrate contents to approaches [1] [3] [6] [18], especially the nature of science in the science classroom. However, this requires reflective practices in teacher education courses and activities that lead them to reflect on their conceptions.

Taking into account the Brazilian scenario of chemistry teacher education, the authors [ARAGAO 2014] researched the conceptions of pre-service chemistry teachers to define the concept of Scientific Literacy (SL) and established the parameters they used to formulate such definition. As a result, we established three fundamentals of SL for science education that can develop students' scientific literacy. The three fundamentals are the following approaches: Inquiry-based Teaching (IBT), ScienceTechnology-Society (STS), and History and Philosophy of Science (HPS) [1].

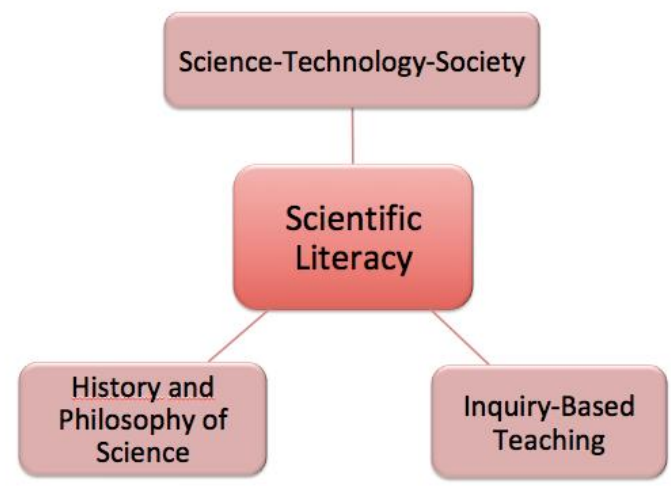

Figure 4. Scientific Literacy and its fundamentals ${ }^{1}$

\section{Methodology}

In order to deepen the research on Scientific Literacy and its fundamentals [1], an investigation was conducted in the discipline "Practice of Teaching Chemistry" in a Brazilian Federal University Science Teacher Education Program was investigated. This discipline content was scientific literacy concept and its fundamentals - Inquirybased Teaching (IBT), Science-Technology-Society (STS), and History and Philosophy of Science (HPS).

Concerning the idea of investigating a teacher education program, we invited a teacher educator to participate in our research. The teacher educator elaborated a course plan for the discipline "Practice of Teaching Chemistry". In this plan, the teacher

\footnotetext{
1 Aragão, Susan Bruna Carneiro. "Alfabetização científica: concepções dos futuros professores de Química. Dissertação (Mestrado) - Universidade de São Paulo. Faculdade de Educação, Instituto de Física, Instituto de Química e Instituto de Biociências. São Paulo, 2014.
} 
educator took into account the difficulties faced by students in a similar discipline in the year before, causing her to rethink some activities, reformulating them, with the aim of allowing pre-service teachers more time for reflection. For instance, one reformulation was pre-service teachers had to write a journal throughout the discipline, in order to promote their reflection about theory and practice.

So, the researcher authors expect that the discipline as it was proposed based on the study and reflection about SL and its three fundamentals can provide means to future chemistry teachers promote SL in secondary chemistry classes.

The research goals are the following:

- analyze conceptions related to Inquiry-based Teaching (IBT), Science-Technology-Society (STS), and History and Philosophy of Science (HPS) approaches and some aspects of the nature of science (NoS) hold by pre-service teachers;

- investigate if and which activities proposed by the teacher educator during the discipline provided the reflecting on pre-service teachers' ideas about the teaching-learning process and scientific literacy concept;

- analyze whether pre-service teachers have acquired the concept of scientific literacy and its fundamentals;

- analyze how pre-service teachers apply scientific literacy and its fundamentals when design lesson plans.

The research question is if the proposal of a discipline, (Practice of Teaching Chemistry) from the perspective of scientific literacy and its fundamentals, can provide the development of preservice teachers' conceptions about scientific literacy?

Twelve pre-service teachers attended this discipline. One of the researchers attended and participated in all 17 classes. Before each class, the teacher educator and the researcher gathered to talk about the previous and the next class. This time of discussion promoted moments of reflection about the pedagogical practice in teacher education.

For this investigation, the data collected through the activities applied by the teacher educator in "Practice of Teaching Chemistry" will be analyzed. Also, the data obtained through the pre-service teachers' journal and semi-structured interviews. The following questions will guide the analyzes:

- Do the conceptions of pre-service teachers throughout the discipline have changed?

- Did the activities proposed by the teacher educator contribute to the reflection of the preservice teachers on their ideas about scientific literacy?

- Did the pre-service teachers take ownership of the concepts of scientific literacy and its fundamentals?
- Did the pre-service teachers apply the concepts on scientific literacy and its fundamentals in the final work (didactic sequence)? In what way?

- What were the actions of the teacher educator that enabled the pre-service teachers to reflect on their practice in the perspective of scientific literacy?

Considering the three fundamentals of scientific literacy to analyze pre-service teachers' conceptions, four levels of understanding of each approach - STS, HPS, IBT - were developed. The levels are described in Table 2.

Table 2. Levels of understanding the fundamentals of

\begin{tabular}{|c|c|c|c|}
\hline \multicolumn{4}{|c|}{$\mathrm{AC}$} \\
\hline Level & STS & HPS & IBT \\
\hline 1 & $\begin{array}{l}\text { The pre-service } \\
\text { teacher does not } \\
\text { recognize the } \\
\text { importance of the } \\
\text { STS approach. } \\
\text { He/she does not } \\
\text { consider aspects } \\
\text { related to the } \\
\text { nature of science. }\end{array}$ & $\begin{array}{l}\text { The pre-service } \\
\text { teacher does not } \\
\text { recognize } \\
\text { importance of the } \\
\text { HPS approach. } \\
\text { He/she does not } \\
\text { consider aspects } \\
\text { related to the nature } \\
\text { of science. }\end{array}$ & $\begin{array}{l}\text { The pre-service } \\
\text { teacher does not } \\
\text { recognize the } \\
\text { importance of the } \\
\text { IBT approach in } \\
\text { science education. } \\
\text { He/she does not } \\
\text { consider aspects } \\
\text { related to the } \\
\text { nature of science. }\end{array}$ \\
\hline 2 & $\begin{array}{l}\text { The pre-service } \\
\text { teacher perceives } \\
\text { the importance of } \\
\text { the STS } \\
\text { approach, but } \\
\text { only to motivate, } \\
\text { inform or } \\
\text { exemplify } \\
\text { scientific } \\
\text { concepts. He/she } \\
\text { does not state a } \\
\text { question- } \\
\text { problem. } \\
\text { Misunderstanding } \\
\text { of aspects of the } \\
\text { nature of science. }\end{array}$ & $\begin{array}{l}\text { The pre-service } \\
\text { teacher perceives the } \\
\text { importance of HPS, } \\
\text { citing facts, dates, } \\
\text { events, and discovery } \\
\text { in isolation (pseudo- } \\
\text { history). He/she does } \\
\text { not state a question- } \\
\text { problem. } \\
\text { Misunderstanding of } \\
\text { aspects of the nature } \\
\text { of science. }\end{array}$ & $\begin{array}{l}\text { The pre-service } \\
\text { teacher perceives } \\
\text { the importance of } \\
\text { the IBT approach, } \\
\text { but only to } \\
\text { motivate, } \\
\text { illustrate, } \\
\text { exemplify or } \\
\text { confirm a theory } \\
\text { already studied. } \\
\text { He/she does not } \\
\text { state a question- } \\
\text { problem. } \\
\text { Misunderstanding } \\
\text { of aspects of the } \\
\text { nature of science. }\end{array}$ \\
\hline 3 & $\begin{array}{l}\text { The pre-service } \\
\text { teacher perceives } \\
\text { and understands } \\
\text { the importance of } \\
\text { the STS } \\
\text { approach. } \\
\text { However, it } \\
\text { prioritizes one of } \\
\text { the dimensions } \\
\text { (science, } \\
\text { technology, or } \\
\text { society), valuing } \\
\text { the teaching of } \\
\text { scientific } \\
\text { concepts or just } \\
\text { the theme. It may } \\
\text { state a question- } \\
\text { problem, which } \\
\text { does not always } \\
\text { allow students to } \\
\text { understand } \\
\text { concepts and } \\
\text { reflect on the } \\
\text { subject. Some } \\
\text { understanding of } \\
\text { aspects of the } \\
\text { nature of science. }\end{array}$ & $\begin{array}{l}\text { The pre-service } \\
\text { teacher perceives and } \\
\text { understands the } \\
\text { importance of the } \\
\text { HPS approach. } \\
\text { He/she understands } \\
\text { science as a dynamic } \\
\text { and collective } \\
\text { knowledge } \\
\text { development, } \\
\text { however, isolated } \\
\text { from other areas } \\
\text { (social, cultural, } \\
\text { political, economic, } \\
\text { technological). Some } \\
\text { understanding of } \\
\text { aspects of the nature } \\
\text { of science. }\end{array}$ & $\begin{array}{l}\text { The pre-service } \\
\text { teacher perceives } \\
\text { and understands } \\
\text { the importance of } \\
\text { the IBT approach, } \\
\text { for teaching } \\
\text { scientific concepts. } \\
\text { He/she states a } \\
\text { question-problem } \\
\text { and proposes a } \\
\text { procedural script. } \\
\text { Students develop } \\
\text { hypotheses; collect } \\
\text { and analyze the } \\
\text { data and draw } \\
\text { conclusions. Some } \\
\text { understanding of } \\
\text { aspects of the } \\
\text { nature of science. }\end{array}$ \\
\hline 4 & $\begin{array}{l}\text { The pre-service } \\
\text { teacher perceives, } \\
\text { understands and } \\
\text { reflects on the } \\
\text { importance of the } \\
\text { STS approach. } \\
\text { He/she } \\
\text { establishes }\end{array}$ & $\begin{array}{l}\text { The pre-service } \\
\text { teacher perceives, } \\
\text { understands and } \\
\text { reflects on the } \\
\text { importance of the } \\
\text { HFC approach. } \\
\text { He/she understands } \\
\text { science a dynamic }\end{array}$ & $\begin{array}{l}\text { The pre-service } \\
\text { teacher perceives, } \\
\text { understands and } \\
\text { reflects on the } \\
\text { importance of the } \\
\text { IBT approach, for } \\
\text { teaching scientific } \\
\text { concepts. He/she }\end{array}$ \\
\hline
\end{tabular}




\begin{tabular}{|c|c|c|c|}
\hline & $\begin{array}{l}\text { relationships } \\
\text { among the } \\
\text { dimensions of } \\
\text { science, } \\
\text { technology, and } \\
\text { society. He/she } \\
\text { states a question- } \\
\text { problem that } \\
\text { enables students } \\
\text { to understand } \\
\text { concepts and } \\
\text { reflect on the } \\
\text { subject. He/she } \\
\text { understands } \\
\text { aspects of the } \\
\text { nature of science. }\end{array}$ & $\begin{array}{l}\text { and collective } \\
\text { knowledge } \\
\text { development that } \\
\text { influences and } \\
\text { suffers influences } \\
\text { from other areas } \\
\text { (social, cultural, } \\
\text { political, economic, } \\
\text { technological). } \\
\text { He/she understands } \\
\text { aspects of the nature } \\
\text { of science. }\end{array}$ & $\begin{array}{l}\text { states a question- } \\
\text { problem proposed } \\
\text { by the students or } \\
\text { by the teacher. } \\
\text { Students develop } \\
\text { hypotheses and the } \\
\text { experimental } \\
\text { procedure; collect } \\
\text { and analyze the } \\
\text { data and draw } \\
\text { conclusions. } \\
\text { He/she } \\
\text { understands } \\
\text { aspects of the } \\
\text { nature of science. }\end{array}$ \\
\hline
\end{tabular}

In this categorization, there are four levels of understanding. Level 1 is related to the nonrecognition of the importance of the approach analyzed, level 2, pre-service teacher perceive the importance of that approach; level 3, pre-service teacher perceive and understand the importance of that approach, and level 4, the highest level, related to the perception, understanding, and reflection of the pre-service teacher of that approach. Also, Bybee's levels of scientific literacy were considered [1]. The levels are: nominal; functional; conceptual and procedural; and multidimensional.

\section{First results and Analysis}

Analyzing the conceptions of one pre-service teacher, categorized in the levels of SL, STS, HPS, and IBT, it is possible to verify that the conceptions varied throughout the classes during the discipline. These results may indicate that the pre-service teacher's conceptions were still in development.

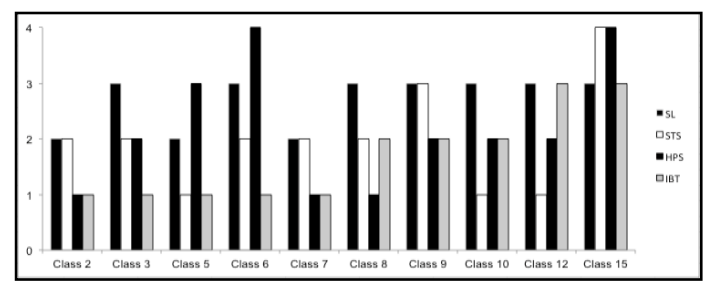

Figure 5. Pre-service teacher conceptions during the discipline Practice of teaching chemistry

Analyzing the results, we can verify that the preservice teacher's ideas about the aspects of NoS, such as the understanding of the development of scientific concepts and criticality, have been manifested in practically all classes. However, throughout the discipline, she may relate these aspects may be related to the STS and HPS approach. She was able to perceive, understand and reflect on these approaches and realize and understand the importance of IBT.

\section{Conclusion}

The discussion about the need of scientific literacy as the main goal of science education lasts long, it has started in the second half of $20^{\text {th }}$ century and endures unto this day. However, no consensus has been established about its definition [1].

Many countries have developed curriculum reforms establishing the goals for science education. Scientific literacy is the aim achievement for most of them [4] [5] [10] [11].

We proposed a model for teacher education discipline from the perspective of scientific literacy and its three fundamentals - Inquiry-based Teaching (IBT), Science-Technology-Society (STS), and History and Philosophy of Science (HPS). This proposal made it possible for the pre-service teacher to perceive, understand and reflect STS and HPS approaches, which was promising as a framework for science teacher education. However, the question posed by Shamos [12], "Why should we teach science?" is still open, although there is no evidence in the literature about this discussion. One possibility is an initiative promoted by the Mackenzie Presbyterian Institute in which developed a worldview, stating ontology precedes epistemology [20]. This more philosophical worldview provided a rich scenario to develop scientific concepts and also some aspect of the nature of science in chemistry textbooks and course materials. Moreover, it also contributes to a more complex view of science, avoiding reductionism. However, this proposal was only analyzed in the development of chemistry textbooks and course materials. It is hoped that the institute will research this worldview in the science classroom.

\section{References}

[1] Aragão, S.B.C. 'Scientific Literacy: prospective teachers' conceptions'. Dissertation (Master degree), University of São Paulo. Institute of Education, Institute of Physics, Institute of Chemistry and Institute of Biology, SãoPaulo,2014.www.teses.usp.br/teses/disponiveis/81/811 32/tde14102015-151323/pt-br.php, (Access Date: 26 September 2018).

[2] Allchin, D. (2013) Teaching Nature of Science: perspectives and resources, Ships Education Press, Minnesota - USA.

[3] Sasseron, L. H., Carvalho, A. M. P. (2011) 'Alfabetização Científica: uma revisão bibliográfica', Investigações em Ensino de Ciências, 16(1), pp. 59-77.

[4] American Association for the Advancement of Science AAAS (2001) 'Project 2061 Science for All Americans Education for a changing future'. Washington, DC: AAAS, http://www.project2061.org/publications/sfaa/ (24 October 2016). 
[5] Millar, R.; Osborne, J. (1998) 'Beyond 2000: Science education for the future - The report of a seminar series funded by the Nuffield Foundation', London: King's College, School of Education, http://www.nuffieldfoundation.org/sites/default/files/Beyond\%202000.pdf $(24$ October 2016).

[6] Santos, W. L. P. and Mortimer, E. F. (2002) 'Uma análise de pressupostos teóricos da abordagem C-T-S (Ciência-Tecnologia-Sociedade) no contexto da educação brasileira', Revista Ensaio, 2(2), pp. 110-132.

[7] Shen, B. (1975) 'Science Literacy: Public understanding of science is becoming vitally needed in developing and industrialized countries alike', American Scientist, pp. 265-268.

[8] Pella, M.O. (1976) 'The place or function of Science for a literate citizenry', Science Education, pp. 97-101, https://doi.org/10.1002/sce.3730600113 (26 September 2018).

[9] Hurd, P. D. 'Scientific literacy: New minds for a changing world' (1998), Science Education, 82(3), pp. 407-416.

[10] Australian Curriculum, Assessment and Reporting Authority - ACARA (2016). http://www.australiancurriculum.edu.au/science/rationale (24 October 2016).

[11] Brasil, Ministério da Educação. Base Nacional Comum Curricular - BNCC 3a versão (2017), Brasília, DF-Brazil http://portal.mec.gov.br/index.php?Option=com _docman\&view=download\&alias=79601-anexo-textobncc-reexportado-pdf-2\&category_slug=dezembro-2017pdf\&Itemid=30192 (21 October 2017).

[12] Shamos, M. H. (1995) 'The Myth of Scientific Literacy', Rutgers University Press, New Jersey - USA.

[13] Carvalho, C. et al. (2011) 'Student Perceptions of Secondary Science Teachers' Practices Following Curricular Change', Journal of Turkish Science Education, 8(1), pp. 29-41.

[14] Bybee, R. W. (1993) 'Reforming Science Education: social perspectives and personal reflections, Teachers College Press, New York-USA.

[15] Aikenhead, G.S. 'What is STS Science Teaching?'https://education.usask.ca/documents/profiles/ai kenhead/sts05.htm (26 September 2018).

[16] Acevedo-Díaz, J. A.; Vázquez, A.; Manassero, M. A. (2003) 'Papel de la educación CTS en una alfabetización científica y tecnológica para todas las personas', Revista Electrónica de Enseñanza de las Ciencias, 2(2), pp. 80-111.

[17] Abd-El-Khalick, F.; Lederman, N. G. (2000) 'The influence of History of Science courses on students' views of Nature of Science', Journal of Research in Science Teaching, 37(10), pp. 1057-1095, 2000.

[18] Colagrande, E. A.; Martorano, S. A. A.; Arroio, A. (2017) 'views of a group of pre-service science teachers on the use of experimental activities in science teaching', problems of education in the $21^{\text {st }}$ century, $75(6)$, pp. 525534.

[19] OECD, 'OECD Indicators, Country note - Brazil' (2011) http://dx.doi.org/10.1787/eag-2011-en, (20 October 2018).

[20] Oliveira, N. S. and Aragão, S. B. C. (2019) 'Chemistry textbook editing - a cross-disciplinary case study', International Journal for Cross-Disciplinary Subjects in Education, (IJCDSE), Volume 9, Issue 4. 